\title{
MED1 Gene
}

National Cancer Institute

\section{Source}

National Cancer Institute. MED1 Gene. NCI Thesaurus. Code C20682.

This gene plays a role in the transcriptional activation of target genes. It is involved in embryonic fibroblast differentiation and normal development of vital organs. 